per cent of biotechnology companies that survive the next five years.

The new chairman of the Biogen board, Professor Walter Gilbert, has been closely associated with the company since its inception in 1978 both as chairman of the board of scientific directors, a role in which he will continue, and as co-chairman of the board of directors (since mid-1979). He moves to the position of chairman with the departure of the other co-chairman, $\mathrm{Dr}$ Robin Nicholson of Inco, to the British Cabinet Office (see p.596). Since the job of chairman is full-time, Professor Gilbert is taking a year's leave of absence from Harvard. And since he hopes to remain as chairman, he is discussing with Harvard University ways and means by which he can permanently keep both his laboratory at Harvard and his position with Biogen.

The American laboratory of Biogen Inc. opens this week on a site two blocks away from the Massachusetts Institute of Technology in Cambridge. It should be staffed with about 35 scientists by the end of the year and may well have a director within weeks. The Cambridge laboratory is destined to concentrate on the more chemical and processing sides of biotechnology, with a particular interest in bacterial methods of producing ethanol and chemical feedstocks. Meanwhile the Geneva laboratory of Biogen SA (the offspring together with Biogen Inc. of Biogen NZ, registered in Curaçao) will continue to concentrate on pharmaceuticals. The Geneva laboratory is itself due to grow rapidly, moving into new premises and doubling in size this year.

All this expansion, for a company that has not yet a single product on sale, needs just the kind of financial backing represented by the $\$ 20$ million deal closed this week with private European financial institutions (insurance companies and banks mainly in the United Kingdom). But when can the backers, which include Inco, General Metropolitan, Schering-Plough and Monsanto, expect to see some return? Professor Gilbert anticipates that Biogen's first sales should be within two years. Bacterially produced human leukocyte interferon is already in the first phase of clinical trial in the Netherlands and both a foot and mouth disease vaccine and a hepatitis $B$ vaccine are being tested in animals. The interferon is being produced in Zurich for Schering-Plough; and Biogen has very recently concluded negotiations with the Japanese pharmaceutical company, Green Cross, for the eventual marketing of a hepatitis $B$ vaccine.

At present Biogen relies on connections with established companies for the marketing side of its business but it plans to become in time (and in the jargon) vertically-integrated. No doubt it also plans to go public in due course but, despite speculation earlier this year, Professor Gilbert will say only that Biogen is a private company and plans to remain so for some time.

Peter Newmark

Biotechnology

\section{UN plans centre}

New York

An International Centre for Genetic Engineering is being planned at the United Nations. Proposed last year by UN officials, the centre would attempt to promote technology transfer between developed and developing nations in a noncommercial setting.

At a meeting in Vienna last February under the auspices of the United Nations Industrial Development Organization (UNIDO), scientists and officials from developing countries worked out a plan for a facility to extend the industrial application of genetic engineering to developing countries. The working model appears to be the International Centre for Theoretical Physics in Trieste. The centre would entertain scientists from both developed and

\section{Aid without reactors}

The United Kingdom Atomic Energy Authority confirmed last week that its Harwell laboratory is acting as a consultant to the King Abdulaziz University in Jeddah, Saudi Arabia, on the development of an international energy research centre. But the authority insists that no part of its brief will be concerned with the provision of nuclear reactors, even for research. Rather, the Harwell laboratory will be giving advice only on the establishment of a laboratory of materials science.

By all accounts (of which there are few), the Jeddah centre is to be a fully fledged research laboratory concerned with all non-fossil sources of energy. One of the objectives is to create a laboratory at which scientists and engineers from outside Saudi Arabia will work alongside local people, thus helping with training, also known as technology transfer. Much of the research programme will be concerned with solar energy with which Saudi Arabia is almost as well endowed as with petroleum.

The importance of a materials science laboratory at the centre stems not merely from the possible use of semiconductor devices for the direct conversion of solar energy into electricity but also from the applications of ceramic and other materials in the fabrication of other solar energy devices, from mirrors to windmills.

The Harwell laboratory is thought to be only one of several consultants; the identities of the others are not known. Its brief appears to involve the specification of laboratory facilities and equipment and the provision of advice on the scale on which research should be carried out. developing nations in order to deal with scientific problems unique to the poorer countries.

The centre would serve as an information network and as a training ground for scientists from developing countries, and might include on-site laboratories for research and development. Suggested projects already include work on vaccines for malaria and other diseases, the transfer of nitrogen-fixation genes to plants and the development of plants resistant to drought and herbicides. Agricultural specialists consulted by the United Nations foresee the creation of high technology plants capable of yielding well even with the relatively less advanced agricultural technology of the poorer nations.

There is, as yet, no indication of where the centre would be located but several countries, including Mexico and Argentina, have expressed an interest. The host country would be expected to put up money to help finance the enterprise. Other financial support would come from UNIDO funds, and UN officials say they are trying to interest several OPEC nations.

UNIDO representatives say the proposal has been well received wherever they have travelled in South America, Asia and the Middle East. But apart from the political problem of where to place such a centre, scientists researching the plan have said that some developed nations represented in the United States by the Department of Commerce and the State Department - have been hesitant to commit themselves wholeheartedly to such a broad transfer of technology.

In addition, some Third World research directors have suggested that they would prefer that the United Nations should invest in factories rather than in building a research centre. They argue that many nations which need the fruits of recombinant DNA technology lack a nucleus of native scientists capable of taking advantage of such a facility.

The next UNIDO meeting takes place in Vienna this month, and the United States, Japan, Pakistan, India, The Netherlands, West Germany and the United Kingdom have so far agreed to attend. Final decisions about the size and location of the proposed centre are expected by January 1982.

Michael D. Stein

\section{Research in Norway Oiling the wheels}

\section{Bergen}

A Norwegian government commission says that spending on the country's industrial science and technology research is grossly inadequate and that a doubling of expenditure in the next few years is needed. It is hoped that industry itself would provide most of the money, although the commission, chaired by banker Lars Uno Thulin, urges the public sector to take an initiative by spending an extra $£ 25$ million 